AperTO - Archivio Istituzionale Open Access dell'Università di Torino

Protecting Foreign Investments in Public Services: Regulatory Stability at Any Cost?

This is a pre print version of the following article:

Original Citation:

Availability:

This version is available http://hdl.handle.net/2318/1645889

since 2018-07-31T18:22:41Z

Published version:

DOI:10.1515/gj-2017-0014

Terms of use:

Open Access

Anyone can freely access the full text of works made available as "Open Access". Works made available under a Creative Commons license can be used according to the terms and conditions of said license. Use of all other works requires consent of the right holder (author or publisher) if not exempted from copyright protection by the applicable law. 


\title{
Protecting Foreign Investments in Public Services: Regulatory Stability at Any Cost?
}

\author{
Francesco Costamagna, University of Turin \& Collegio Carlo Alberto
}

\begin{abstract}
The article addresses the tension between regulatory stability and regulatory change within the international regime for the protection of foreign investments. The work focuses on public services, a sector where striking a balance between stability and change has been highly problematic. In this context, modifications of the regulatory framework may substantially affect the profitability of investments that normally presuppose large network infrastructures. On the other hand, adapting the regulatory framework to ever-changing social needs is crucial to pursue fundamental social purposes.

The article deals with this tension through the prism of the fair and equitable treatment standard and the protection of investors' legitimate expectations. The analysis shows that there has been an evolution in the arbitral practice, but that there is still considerable uncertainty on key aspects. The paper proposes the adoption of an interpretive approach that can help ease the tension between stability and change.
\end{abstract}

Keywords: change, FET, legitimate expectations, regulation, stability

\section{Introduction}

The international regime for the protection of foreign investments has gained unprecedented visibility over the past decade, due to the growth in the number of international investment agreements and, more importantly, the boom of investorState arbitration. This evolution has raised concerns about its impact on States' regulatory autonomy. Indeed, the reach of these disputes goes well beyond mere commercial matters to encompass key aspects of host States' socio-economic order.

The regulation of public services is one of the main examples in this regard. Over the past few years, there have been a growing number of cases concerning measures taken by host States to regulate foreign investments in this sector. This evolution has been aided and abetted by liberalization and privatization policies 
that, since the late 1970s, have spread all over the world. This process has opened up new spaces for the participation of private actors in a sector traditionally dominated by State-owned or State-controlled entities. However, the relationship between the private party and the public authority has often proved difficult, for both technical and socio-political reasons, often ending up before an international arbitral panel.

A key concern in this context is reconciling regulatory change and regulatory stability. In the case of public services, the relationship between the two conditions is even more problematic than in other economic sectors. Indeed, modifications of the regulatory framework may substantially affect the profitability of investments that normally presuppose the existence of large network infrastructures and, consequently, entail high levels of sunk costs and long payback periods. Regulatory stability is thus a paramount concern for foreign investors and, according to some commentators and arbitral tribunals alike, it is a priority of the entire protection system. On the other hand, adapting the regulatory framework to ever-changing social needs and challenges is crucial for public services to be able serve their fundamental social purposes. The continuous exercise of regulatory powers now represents the main instrument at the disposal of national authorities to ensure that these services can contribute to fulfilling peoples' everyday needs and to enhancing social cohesion.

The outcome of this exercise depends greatly on the approach taken by international arbitrators to define treaty provisions and, in particular, on their capacity and willingness to pay due regard to the fact that these activities are not ordinary business operations being them functional to the pursuit of fundamental social objectives. Therefore, when assessing whether a change to the regulatory framework in which the investment operates complies with international protection standards, it is necessary to respect the host State's capacity to regulate in the public interest.

This article focuses on the protection of investors' legitimate expectations within the fair and equitable treatment, proposing an interpretive approach that allow for the reconciliation of stability and change in this context. To this end, the article first deals with the notion of regulation in the public service sector by exploring its categorization as a right and/or a duty of States. The analysis then examines the increasingly important role played by the fair and equitable 
treatment standard in arbitral practice, also with regard to public services' cases. In particular, the article considers the difficulties of finding an equilibrium between stability and change in the public services' sector by examining the impact of the legitimate expectations doctrine upon host States' capacity to modify the regulatory framework in which the investment operates. The article takes a critical stance toward early arbitral award, which took a markedly proinvestor and pro-stability approach. Lastly, building on more recent arbitral decisions, the article calls for the adoption of a three-steps interpretive approach that may contribute to ease the tension between stability and change in a highly sensitive sector.

\section{Public Services' Regulation and its Impact upon Foreign Investments: Change vs. Stability}

The role of the State in the provision of public services has markedly changed in recent decades, mainly because of the impact of the liberalization and privatization policies that have been variously adopted and implemented by several countries around the world. Some of the functions traditionally exercised by public authorities have been progressively transferred to private or mixed actors. However, public authorities are still expected to intervene in order to ensure that public services are organized and provided in a way that preserves their specific function. Indeed, these services cannot be fully equated with other economic activities because they are vital for fulfilling peoples' everyday needs, enhancing social cohesion, and fostering economic growth. Ensuring (universal) access to high-quality public services is widely regarded as one of the key functions of the State.

Especially in those cases where public services have been liberalized or privatized, regulation is the main instrument at the disposal of public authorities to perform this function. Before proceeding with the analysis, it is worth observing that the notion of 'regulation' has an uncertain legal meaning, at least under international law. This paper will use the term in a broad sense encompassing all the measures taken by public authorities to "influenc[e], control[...] and guid[e] economic or other private activities with impact on others", ${ }^{1}$ the purpose being to

\footnotetext{
${ }^{1}$ M. Krajewski, National Regulation and Trade Liberalization in Services (Kluwer Law International 2003) 4.
} 
achieve specific socio-economic policy objectives. ${ }^{2}$ It should be stressed that the term 'public authorities' is meant to cover not just central authorities, but also independent agencies or bodies, as well as local authorities, which play a major role in the regulation of public services.

A distinction is often drawn between economic and social regulation, depending on the objectives that it pursues. ${ }^{3}$ Economic regulation mainly aims at correcting market failures ${ }^{4}$ that, according to the neo-classical economic theory, may lead to an inefficient allocation of resources, if not properly regulated. Some of these failures are particularly relevant to public services, as is the case of natural monopolies. Indeed, the supply of public services normally requires the existence of expensive network infrastructures that cannot be duplicated so as to allow the entry of new competitors. Therefore, there is the need to prevent the provider from exploiting its monopolistic power by, for instance, charging excessive fees to end-users.

Regulation performs functions that go beyond the correction of market failures because it may address distortions that occur even in cases where the market works properly. Indeed, economic efficiency does not necessarily entail a fair distribution of costs and benefits. Consequently, there is a need for the State to intervene in order to ensure that public services can contribute to the achievement of fundamental social objectives. ${ }^{5}$ This may occur through the imposition of public service obligations upon the provider or the providers. These obligations, which may take different forms and have different purposes, are generally geared to ensuring the affordability, geographical coverage and quality of public services' supply. ${ }^{6}$

\footnotetext{
2 The Glossary of Industrial Organisation Economics and Competition Law, compiled by R.S. Khemani and D.M. Shapiro, commissioned by the Directorate for Financial, Fiscal and Enterprise Affairs (OECD 1993) defines regulation as the imposition of rules by government, backed by the use of penalties that are intended specifically to modify the economic behaviour of individuals and firms in the private sector". An equally broad definition is used by B.M. Mittnick, The Political Economy of Regulation (Columbia University Press 1980) 1. The Author defines regulation as 'the intentional restriction of a subject's choice of activity by an entity not directly party or involved in that activity'.

${ }^{3}$ This distinction is not to be taken too rigidly, as regulatory measures normally pursue different types of objectives simultaneously. See Krajewski (n. 1) 18.

${ }^{4}$ R. Baldwin, M. Cave, Understanding Regulation - Theory, Strategy and Practice (Oxford University Press 1999) ch. 2. Conversely, according to the private interest theories of regulation, regulatory functions are not meant to serve the public interest because they are captured by powerful private groups. See E. Dal Bò, 'Regulatory Capture: A Review' (2006) 22 Oxford Review of Economic Policy 203, 203-225.

${ }^{5}$ G. Palast, J. Oppenheimer and T. Macgregor, Democracy and Regulation: How the Public Can Govern Essential Services (Pluto Press 2003).

6 I. Houben, 'Public Services Obligations: Moral Counterbalance of Technical Liberalization Legislation' (2008) 16 European Review of Private Law 7, 7-27.
} 
Public services are by no means the only economic sector where States exercise their regulatory functions. However, in this context, regulation plays a role that is far more important than in other economic sectors because it has a 'constitutive' value. Indeed, the exercise of regulatory functions by public authorities, through the imposition of specific obligations on the supply of the service, marks the existence of a 'public service' and distinguishes it, also with regard to its legal status, from other economic activities. This is what is called the 'objective' approach to the definition of 'public service', so as to distinguish it from the traditional 'subjective' understanding of the notion. The latter derives from the French doctrine of service public and tends to identify public services by looking at the subject providing them, which is the State or a State-controlled entity. ${ }^{7}$ The objective definition of public services has gained increasing recognition in recent times because it better reflects the evolution of the role of the State in the provision of public services. For instance, this definition is commonly used in the EU legal order to define the notion of 'services of general economic interest', an expression which is used in that context to avoid the ambiguities deriving from the use of 'public services' ${ }^{8}$ In 2003, the European Commission explained that the concept, which can be found in Article 106.2 TFEU, refers to "services of an economic nature which the Member States or the Community subject to specific public service obligations by virtue of a general interest criterion". 9

As observed by Lowe with regard to regulation in general, the exercise of regulatory functions is "an essential element of the permanent sovereignty of each State over its economy" ${ }^{10}$ and it must consequently be considered as a sovereign right. The existence of such a right has been recalled by the GATS, whose Preamble reiterates the need to respect "the right of members to regulate, and to introduce new regulation, on the supply of services within their territories in order

\footnotetext{
7 See M. Hariou, Précis de droit administratif et de droit public (Sirey 1927); G. Jèze, 'Le service public' (1926) Revista de Drept Public 167, 171-172.

${ }^{8}$ But these efforts seem to have been to little avail because the notion of services of general economic interest, as well as its relationship with other related concepts, such as that of services of general interest, is still uncertain and has generated much confusion. See generally U. Neergaard, 'Services of General Economic Interest: The Nature of the Beast', in M. Krajewski, U. Neergaard and J. Van de Gronden (eds), The Changing Legal Framework for Services of General Interest in Europe (TMC Asser Press 2009) 17-50.

${ }^{9}$ European Commission, Green Paper on Services of General Interest (2013) COM(2003) 270 def., 17.

${ }^{10}$ V. Lowe, 'Regulation or Expropriation?', (2002) 55 Current Legal Problems 447, 450-451.
} 
to meet national policy objectives". ${ }^{11}$ The need to preserve States' regulatory autonomy seems to have finally made its way also into international investment agreements, being couched in terms that strongly recall those used in the GATS. ${ }^{12}$ For instance, in Article 8.9, paragraph 1, of the Investment Chapter of the EUCanada Comprehensive Economic and Trade Agreement (CETA) the Parties "reaffirm their right to regulate within their territories to achieve legitimate policy objectives". 13

Preserving host State's capacity fully to exercise its regulatory powers is all the more important with regard to public services, as their provision represents one of State's core sovereign functions and, ultimately, its very raison d'être. The role of public services as constitutive elements of the State had already been emphasised in the early nineteenth century by the so-called School of Bordeaux. In particular Leon Duguit, the founder of the School, criticized the assimilation of the State to the concept of puissance public, ${ }^{14}$ instead conceiving it as a "cooperation de services publics organisés et controlés par des gouvernants". ${ }^{15}$ This approach still retains its value because public services continue to be "a key element of the modern social and welfare state" 16 and a building block of its legitimacy.

The adoption of a less State-centric vision has opened up new perspectives on the regulation of public services, which is now increasingly considered as a duty

\footnotetext{
11 The recognition of this right sought to respond to the concerns that the adoption of GATS might jeopardize States' capacity to regulate services and, in particular, public services. The WTO website also features a section devoted to "Misunderstanding and scare stories: The right to regulate" (< http://www.wto.org/english/tratop_e/serv_e/gats_factfiction11_e.htm> accessed on 27 October 2016). On the relationship between trade and public services see A. Arena, 'The GATS Notion of Public Services as an Instance of Intergovernmental Agnosticism: Comparative Insights from the EU Supranational Dialectics', (2011) 45 Journal of World Trade 489, 489-528; M. Krajewski, 'Public Services and Trade Liberalization: Mapping the Legal Framework' (2003) 6 Journal of International Economic Law 341, 341-367; R. Adlung, 'Public Services and the GATS' (2005) 9 Journal of International Economic Law $455,455-485$.

12 This is just another example of the tendency by international investment agreements to borrow from the WTO system, in the attempt to rebalance economic and non-economic concerns within the international regime for the protection of foreign investments. On this trend see generally J. Kurtz, The WTO and International Investment Law (Cambridge University Press 2016).

13 The Agreement has been signed on 30 October 2016 after that negotiations were concluded in August 2014. A consolidated version of the Agreement can be accessed here: <http://data.consilium.europa.eu/doc/document/ST-10973-2016-INIT/en/pdf > accessed on 31 October 2016.

${ }^{14}$ See M. Hariou, Precis de droit administratif et droit public (Larose 1901) 26-27.

15 L. Duguit, Traité de droit constitutionel. Tome cinquiéme. Les libertés publiques (Ancienne Librairie Fontemoing 1925) 55.

16 M. Krajewski, 'Investment Law and Public Services', 3 available at <http://papers.ssrn.com/sol3/papers.cfm?abstract_id=2038514> accessed on 27 October 2016).
} 
of the State and not just a sovereign right. ${ }^{17}$ This evolution has mainly taken place with regard to the objective of ensuring the full protection of human rights, and, in particular, social and economic rights. It is worth observing, due to its importance for this inquiry, that the debate has mostly centred on States' responsibilities in those cases where the supply of essential services has been entrusted to private operators. ${ }^{18}$ There is now consensus on the fact that the choice of outsourcing public services' provision to private actors does not absolve the State from the realization of rights and, hence, from making use of all the regulatory tools at its disposal to this end. For instance, in 2007 the UN High Commissioner for Human Rights, after recalling that international human rights law is neutral with respect to the operational arrangement adopted for the provision of services, confirmed that "Governments and public officials remain primarily responsible for ensuring progress toward the realization of rights" and, consequently, they "must take measures to ensure that limited resources, public as well as private, are used in the most effective manner to promote the realization of rights, giving particular attention to improving the situation of those most in need". ${ }^{19}$ This argument has been reiterated and better specified with particular regard to the right to water and sanitation. The Human Rights Council, in a Resolution adopted in 2010, reaffirmed that "the delegation of the delivery of safe drinking water and/or sanitation services to a third party does not exempt the State from its human rights obligations" and called upon States to adopt a detailed series of measures to fulfil their duties. Inter alia, States are urged to develop appropriate tools and mechanisms "to achieve progressively the full realization of human rights obligations related to safe drinking water and sanitation, including in currently unserved and underserved areas" and "to adopt and implement effective regulatory frameworks for all service providers in line with the human rights

\footnotetext{
${ }^{17}$ See High Commissioner for Human Rights, Economic, Social and Cultural Rights. Handbook for National Human Rights Institutions (United Nations 2005), 18 where it states that " $[\mathrm{t}]$ he obligation to fulfil economic, social and cultural rights ... can entail issues such as ... the provision of basic public services and infrastructures".

${ }^{18}$ C. Graham, 'Human Rights and the Privatization of Public Utilities and Essential Services', in K. De Feyter and F. Gómez Isa (eds), Privatization and Human Rights in the Age of Globalization (Intersentia 2005) 33-56.

${ }^{19}$ Report of the United Nations High Commissioner for Human Rights to ECOSOC (focusing on the concept of progressive realization of economic, social and cultural rights), UN Doc. E/2007/82 of 25 June 2007, parr. 34-36.
} 
obligations of States". ${ }^{20}$

The exercise of regulatory functions by the host States with regard to public services has a profound impact on the investments made in this sector. The viability and the profitability of the activity carried out by the investor is heavily dependent on the regulatory choices adopted by the competent authorities with regard, for instance, to the obligations to be fulfilled in supplying the service or the mechanism for the calculation of tariffs. This dependence is made more acute by the fact that these investments normally presuppose the existence of large network infrastructures and, consequently, entail high levels of sunk costs and long payback periods. On the one hand, investors are 'hostage' to the host State because assets cannot be moved elsewhere. On the other hand, infrastructure investments are particularly exposed to the so-called obsolescing bargain phenomenon, ${ }^{21}$ which may occur after the bulk of the investment has been made and the host government, mostly for political or just electoral reasons, seeks to force a revision of the terms of the agreement with the investor by resorting to its sovereign powers. This is what happened in the Vivendi II case, where the newlyelected authorities of the Province of Tucumán did everything in their power to undermine the privatization of water and sewage services which had been enacted by the earlier administration. To this end, they mounted what the arbitral tribunal defined "an illegitimate campaign against the concession" ${ }^{22}$ by using their regulatory powers to put pressure on the concessionaire.

\section{Regulatory Change vs. Regulatory Stability in the Context of Public} Services through the Lens of the Fair and Equitable Treatment: Taking Stock

\subsection{Stability and Protection of Legitimate Expectations as Elements of the Fair} and Equitable Treatment Standard: Issues of Why and How

The fair and equitable treatment (FET) standard has acquired an increasingly

\footnotetext{
${ }^{20}$ Resolution adopted by the Human Rights Council. Human Rights and Access to Safe Drinking Water and Sanitation (2010) A/HRC/RES/15/9.

${ }^{21}$ See R. Vernon, 'Long-Run Trends in Concession Contracts' (1967) Proceedings of the American Society for International Law 81, 81-89. See more recently E.J. Woodhouse, 'The Obsolescing Bargain Redux? Foreign Investment in the Electric Power Sector in Developing Countries' (2006) 38 New York Journal of International Law and Policy 121, 121-219.

${ }^{22}$ Compañia de Aguas del Aconquijia S.A. and Vivendi Universal S.A. v. The Argentine Republic, ICSID Case No. ARB/97/3, Award (20 August 2007) para. 7.4.19.
} 
important role in the debate on the balance between host States' regulatory flexibility and foreign investors' need for regulatory stability under international investment law. It has progressively taken precedence over the discipline of expropriation. The standard was long "a sleeping beauty" 23 in the international regime for the protection of foreign investors because arbitral tribunals 'discovered' it only in the 2000s. However, in a few years it has become the most frequently invoked standard in investment disputes ${ }^{24}$ or, as pretentiously stated in AWG/Suez, "the Grundnorm or basic norm of international investment law". 25

There are two main reasons for its success. First, the FET is less politically charged than other standards as "it provides a more supple way of providing a remedy appropriate to the particular situation as compared to the more drastic determination and remedy inherent in the concept of regulatory expropriation". ${ }^{26}$ Second, much emphasis has been put on the alleged intrinsic vagueness ${ }^{27}$ of an "amorphous concept", ${ }^{28}$ allowing international arbitrators to progressively broadening the scope of application of the standard to foreign investors' advantage. Some scholars have gone so far as to argue that the use of an "intentionally vague term" was specifically meant to "give adjudicators a quasilegislative authority to articulate a variety of rules necessary to achieve the treaty's object and purpose". ${ }^{29}$ This overstatement of the role and functions of arbitral tribunals clearly evidences the mindset that allowed FET to become a sort of "catch all provision which may embrace a very broad number of governmental acts", ${ }^{30}$ having a potentially considerable impact on the freedom of a government

\footnotetext{
${ }^{23}$ C. Schreuer, 'Fair and Equitable Treatment in Investment Treaty Law', in F. Ortino, L. Liberti, A. Sheppard and H. Warner (eds), Investment Treaty Law. Current Issues II (British Institute of International and Comparative Law 2007), 92.

${ }^{24}$ R. Dolzer, 'Fair and Equitable Treatment: A Key Standard in Investment Treaties' (2005) 39 The International Lawyer, 87, 87.

${ }^{25}$ Suez, Sociedad General de Aguas de Barcelona S.A. and Vivendi International S.S. v. The Argentine Republic, ICSID Case No. ARB/03/19 and AWG Group Ltd. v. The Argentine Republic, UNCITRAL Case, Decision on Jurisdiction (3 August 2006), para. 188.

${ }^{26}$ International Thunderbird Gaming v. The United Mexican States, UNCITRAL (NAFTA), Arbitral Award (26 January 2006), Separate Opinion of Prof. T. Wälde. See also Sempra Energy International v. The Argentine Republic, ICSID Case No. ARB/02/16, Award (28 September 2007) para. 301.

${ }^{27} \mathrm{~S}$. Schill, 'Fair and Equitable Treatment under Investment Treaties as an Embodiment of the Rule of Law', IILJ Working Paper 2006/6, 5.

${ }^{28}$ B. Choudhury, 'Evolution or Devolution? Defining Fair and Equitable Treatment in International Investment Law' (2005) 6 Journal of World Investment and Trade 297, 297.

${ }^{29}$ C. Brower II, 'Structure, Legitimacy and NAFTA's Investment Chapter' (2003) 36 Vanderbilt Journal of Transnational Law 37, 66.

${ }^{30}$ Dolzer (n. 24) 88.
} 
to regulate its economy. ${ }^{31}$

Over the years, arbitral tribunals have identified a number of elements that give substance to the standard. One of the components is host States' obligation to respect and protect foreign investors' legitimate expectations with respect to the investment that they have made. This aspect has rapidly gained a prominent role in the definition of FET, becoming one of its key ingredients or, even, "the dominant element of that standard". 32 The increasingly important role played by this element in defining the content of FET is highly relevant for our analysis. Indeed, as aptly observed in a UNCTAD report on FET, "[t]he concept of legitimate expectations is connected to the phenomenon of "change"",33 and, in particular, to the possibility for national authorities to exercise their regulatory power in a way that modifies, even substantially, the legal environment in which the investment was decided and made.

The success of the legitimate expectation doctrine rests on a considerable amount of uncertainty as to the legal basis for the inclusion of this duty in the FET standard, as well as to the identification of the theoretical justification for such an inclusion. Indeed, lack of rigour in the analysis on the roots of the notion often goes hands in hands with the absence of a clear definition of the function that this element is to perform in the context of FET and, more broadly, within the international regime for the protection of foreign investments.

The obligation to protect investors' legitimate expectations does not find any explicit normative anchoring, because no investment treaty refers to it when defining the FET. ${ }^{34}$ Arbitral tribunals have relied on a disparate set of grounds without paying much attention to their solidity. Some of them have referred to the good faith principle, as it would allegedly requires "the Contracting Parties to provide to international investments treatment that does not affect the basic expectations that were taken into account by the foreign investor to make the

\footnotetext{
${ }^{31}$ Lowe (n. 10) 455.

32 Saluka v. Czech Republic, UNCITRAL, Partial Award (17 March 2006) para. 301.

${ }^{33}$ UNCTAD, Fair and Equitable Treatment. A Sequel, Series on Issues in International Investment Agreements II (UN Publication 2012), 63. See also M. Hirsch, 'Between Fair and Equitable Treatment and Stabilization Clause: Stable Legal Environment and Regulatory Change in International Investment Law' (2011) 12 Journal of World Investment and Trade 783, 786.

${ }^{34}$ M. Potestà, 'Legitimate Expectations in Investment Treaty Law: Understanding the Roots and the Limits of a Controversial Concept' (2013) 28 ICSID Review - Foreign Investment Law Journal 88, 90.
} 
investment". ${ }^{35}$ However, this approach has been rightly criticized on the grounds that the reference to the principle of good faith "does not suffice to explain why a treaty standard such as fair and equitable treatment should be read as encompassing the particular sub-element of the duty to protect legitimate expectations". ${ }^{36}$ Equally unconvincing appears to be the choice made by other tribunals to rely on a selectively purposive reading of the notion of FET, observing that the preamble of some BITs recognizes "that the fair and equitable treatment is desirable in order to maintain a stable framework for investments". 37 This approach, although apparently in line with the one codified by the 1969 Vienna Convention, tends to disregard the sequence provided for therein, by jumping directly to the second step, which concerns the purpose of the Treaty, and not first giving words their literal meaning. Additionally, often arbitrators decided to focus on just one of the many resounding objectives normally contained in investment treaties' preambles, without providing any valid reason for this selective approach. Lastly, many arbitral tribunals have not even tried to find a solid legal ground for the inclusion of obligations to protect foreign investors' expectations within the FET, since they have simply pointed to the existence of "an overwhelming jurisdictional trend" going in that direction. ${ }^{38}$ This approach has been rightly criticized since, as rightly observed by Michele Potestà, "[r]esort to 'precedent' should be no substitute for analysis - especially if such an analysis is not to be found in early awards on which subsequent tribunals rely". ${ }^{39}$

In the attempt to provide a more solid justification as to whether host States are bound to respect foreign investors' legitimate expectations, a number of scholars posited that the protection of legitimate expectations can be considered as a general principle of law. This conclusion rests on the use of a comparative analysis that leads these authors to observe that the notion at stake is "rooted in

35 Técnicas Medioambientales Tecmed, S.A. v. United Mexican States, ICSID Case No. ARB(AF)/00/2, Award (29 May 2003) para. 154.

36 Potestà (n. 34) 92. See also T. Gazzini, 'General Principles of Law in the Field of Foreign Investment' (2009) 10 Journal of World Investment and Trade 103, 117.

${ }^{37}$ CMS Gas Transmission Company v. The Republic of Argentina, ICSID Case No. ARB/01/8, Final Award (12 May 2005).

${ }^{38}$ El Paso Energy International Company v. The Argentine Republic, ICSID Case No. ARB/03/15, Award (31 October 2011) para. 355. See also $A W G /$ Suez (n. 25) para. 222. In the latter case, the Tribunal simply observed that "[i]n an effort to develop an operational method for determining the existence or non-existence of fair and equitable treatment, arbitral tribunals have increasingly taken into account the legitimate expectations that a host country has created in the investor and the extent to which conduct by the host government subsequent to the investment has frustrated those expectations".

39 Potestà (n. 34) 91. See also A. Roberts, 'Power and Persuasion in Investment Treaty Interpretation: The Dual Role of States' (2010) 104 American Journal of International Law 179, 179. 
principles of domestic administrative law that are common to a number of different legal systems". ${ }^{40}$ From this point of view, the protection of legitimate expectations is not just an element of a treaty standard - the FET - but a selfstanding obligation or, to put it differently, an example of those "treatyoverarching rules of international investment rules" that arbitral decisions can create when they "function as a mechanism of global governance". ${ }^{41}$ Although far more refined than those seen above, this approach is controversial, especially from a methodological perspective. Indeed, the comparative analysis employed to determine whether the protection of legitimate expectations is a general principle of law has often been thin and selective. On the one side, the analysis tended to gloss over, or even disregard, the often-profound differences that characterize the enforcement in different national systems of principles, as it is the case with regard to legitimate expectations, that are common just by name. ${ }^{42}$ On the other side, it has been convincingly demonstrated the tendency by the proponents of this approach to take into consideration just selected legal systems, focusing on developed States while largely excluding those from the developing World. ${ }^{43}$

This article takes the view that there is no need to look beyond the language and purpose of FET treaty provisions to find a sufficiently solid legal ground for considering the respect of foreign investors' legitimate expectations as a constitutive element of the standard at stake. In this regard, it is difficult to agree with Arbitrator Pedro Nikken, who argued that "the assertion that fair and equitable treatment includes an obligation to satisfy or not to frustrate the legitimate expectations of the investor ... does not correspond, in any language, to the ordinary meaning to be given to the terms "fair and equitable"", 44

Furthermore, treaty provisions, interpreted in accordance with the rules codified by the 1969 Vienna Convention, are the first element that arbitral tribunals - acting as international law adjudicators - have to consider when

\footnotetext{
40 Potestà (n. 34) 89. See generally E. Snodgrass, 'Protecting Investors' Legitimate Expectations. Recognizing and Delimiting a General Principle’ (2006) 21 ICSID Review 1, 1-58.

${ }^{41}$ S. Schill, 'International Investment Law and Comparative Public Law - An Introduction', in S. Schill (ed.), International Investment Law and Comparative Public Law (Oxford University Press, 2010) 19.

${ }^{42}$ As admitted even by some of the proponents of this approach, see Potestà (n. 34) 97-98.

43 J. Kurtz, 'The Shifting Landscape of International Investment Law and Its Commentary' (2012) 106 American Journal of International Law 686, 693.

${ }^{44}$ See Suez, Sociedad General de Aguas de Barcelona S.A. and Vivendi International S.S. v. The Argentine Republic, ICSID Case No. ARB/03/19 and AWG Group Ltd. v. The Argentine Republic, UNCITRAL Case, Decision on Liability (30 July 2010) Dissenting Opinion of Arbitrator Pedro Nikken, para. 3.
} 
defining the limits of the protection afforded to legitimate expectations in the context of FET or, in other words, the function that this element should play therein. The emphasis put on the vagueness of FET provisions, which has been largely instrumental to justify unduly broad interpretation of the standard, is a bit overdue. A growing number of investment agreements contain textual elements that are relevant to define the level of protection afforded to stability and legitimate expectations within the FET. ${ }^{45}$ For instance, Article 10 of the Energy Charter Treaty put much emphasis on stability and it draws an explicit link between this element and FET, establishing that Contracting Parties have to "encourage and create stable, equitable, favourable and transparent conditions for Investors of other Contracting Parties", by according them at all times fair and equitable treatment. Conversely, Article 8.2, paragraph 2, CETA, specifies that "for greater certainty, the mere fact that a Party regulates, including through a modification to its laws, in a manner which negatively affects an investment or interferes with an investor's expectations, including its expectations of profits, does not amount to a breach of an obligation under this Section". These two examples demonstrates that arbitral tribunals cannot flesh out the substantive content of the obligation to protect legitimate expectations once and for all, by simply referring to allegedly overarching principles, but they need to first engage with the language of applicable treaty provisions.

Moreover, arbitral tribunals have to interpret FET provisions in the light of the treaty's purposes, avoiding considering some of them as the dominant ones, in order to maximise the protection of foreign investment at the expenses of competing interests and values. More recent arbitral decisions offers a more balanced reading of treaties' preambles, giving adequate consideration also to those objectives, such as safeguarding host States' capacity to modify the regulatory framework, that are potentially at odds with regulatory stability. ${ }^{46}$

Should the interpretive methods codified in the 1969 Vienna Convention fail to offer a clear answer, arbitral tribunals could turn to the experience of other

\footnotetext{
45 This is one of the main aspects taken into consideration by States seeking to better define investment agreements' substantive standards, in order to reduce the possibility of successful challenges against their regulatory measures. See C. Henckels, 'Protecting Regulatory Autonomy Through Greater Precision in Investment Treaties: The TPP, CETA and TTIP' (2016) 19 Journal of International Economic Law 27, 27-50.

46 Continental Casualty Company v. The Argentine Republic, ICSID Case No. ARB/03/9, Award (5 September 2008) para. 458
} 
legal systems that have already dealt with these issues. However, the comparative inquiry is to be carried out with extreme caution, so to avoid engaging in blind transplants of solutions that do not suit the structure and function of international investment arbitration. The first element that calls for careful evaluation is the selection of comparators. On this issue, this article by and large share the perspective recently taken by Henckels, according to whom international arbitral tribunals should take into consideration the decisions of other international bodies charged with "the adjudication of domestic regulatory and administrative measures for compliance with a government's treaty obligation", ${ }^{47}$ and not those of national courts. ${ }^{48}$ Even though international arbitral tribunals are called upon to adjudicate challenges brought against national administrative and regulatory choices, they cannot be analogized to national courts, since they are not embedded in a national polity and they lack the institutional checks that normally exist within domestic public law regimes. ${ }^{49}$ The adoption of such perspective reduces the number of possible comparators to just a few. With specific regard to the notion of legitimate expectations, there seems to be two comparators that stands out in this regard: the European Court of Human Rights (ECHR) and the Court of Justice of the European Union (CJEU). However, the call for caution issued above and aimed at preventing the risk of crude transplants of solution elaborated elsewhere, also applies with regard these two courts. Indeed, international arbitrators needs to pay due consideration to the differences that may exist between expectations that may arise in the context of an economic operation and those protected under a human rights treaty. This is even more the case when taking into consideration how this notion is defined and applied by a court, such as the CJEU, which operate in a system that has unique institutional features and pursues goals that are alien to the international regime for the protection of foreign investments. And yet, relying upon the experience of both these courts can help international arbitral tribunals to work out a more principled approach when it comes to identifying the limits of the protection of legitimate expectations and, thus, finding a balance between regulatory stability and change in the context of

\footnotetext{
${ }^{47}$ C. Henckels, Proportionality and Deference in Investor-State Arbitration. Balancing Investment Protection and Regulatory Autonomy (Cambridge University Press 2015) 12-16.

48 Contra Schill (n. 41) 16.

${ }^{49}$ Kurtz (n. 43) 693. See, more generally, J. Alvarez, 'Beware: Boundary Crossing - A Critical Appraisal to Public Law Approaches to International Investment Law', 17 Journal of World Investment \& Trade 171, 171-228.
} 
FET.

\subsection{Regulatory Stability at Any Cost: The Early Argentine Cases}

The need to find a workable balance between stability and change is all the more urgent in the field of public services. As seen above, regulatory changes may substantially affect the economic profitability of projects that normally presuppose the existence of large network infrastructures and, consequently, entail high levels of sunk costs and payback periods, while assets cannot be moved elsewhere. On the other hand, there is the need to ensure an adequate regulatory space to national authorities so that they may continuously exercise their sovereign function by adapting the regulatory framework to ever-changing needs and challenges.

The case of Argentina provides a vivid illustration of the problems that tarnish the relationship between the protection of foreign investors' legitimate expectations and the safeguarding of host States' regulatory autonomy in the field of public services. As is well known, in the early 2000s, the growth of public debt drove Argentina into recession, causing massive protests and social unrest because most of the country's households were no longer able to cope with everyday life expenses. In order to guarantee access to basic public services, such as water, sewage, electricity and gas, the Government first forced private investors to accept a temporary freezing of tariffs and, subsequently, adopted the Ley de Emergencia, establishing that tariffs and prices for public services were to be calculated in pesos, abolishing all clauses calling for tariff adjustments in US dollars or other foreign currencies, eliminating all indexing mechanisms, and directing the executive branch to renegotiate all public service contracts. Many foreign investors resorted to international arbitration, ${ }^{50}$ claiming that these measures violated several provisions of the bilateral treaties concluded by Argentina with their home countries. In particular, claimants contended that Argentina had failed to treat them fairly and equitably, arguing that the challenged measures represented a substantial modification of the legal framework devised in the early 1990s to support the public utilities' privatization programmes and were, thus, a violation of the expectations created by the guarantees on which private

\footnotetext{
${ }^{50}$ See generally W.W. Burke-White, 'The Argentine Financial Crisis: State Liability under BITs and the Legitimacy of the ICSID System', in M. Waibel (ed.), The Backlash Against Investment Arbitration: Perceptions and Reality (Kluwer Law International 2010) 407-432.
} 
investors had relied when deciding to invest.

Unsurprisingly, the need to strike a balance between these competing interests was recognized, at least on paper, in all cases concerning public services. Each arbitral decision acknowledged that the duty to ensure the stability and predictability of the regulatory framework does not entail the immutability of the legal order. Or, as said in $C M S$, "[i]t is not a question whether the legal framework might need to be frozen as it can always evolve and be adapted to changing circumstances, but neither is it a question of whether the framework can be dispensed with altogether when specific commitments to the contrary have been made". ${ }^{51}$ This dictum progressively acquired an iconic status, being quoted in all subsequent decisions dealing with the matter. However, in many cases it turned out to be an empty formula, or, as aptly observed in El Paso, "a general statement of principle with no legal consequences on the settlement of the case". 52

Although rather harsh in its tone, the latter remark reflects the criticisms levelled against an early line of decisions that adopted a markedly pro-investor stance, paying little attention to the host State's capacity to adapt the legal framework governing the provision of public services to a deteriorating economic situation. In particular, early arbitral decisions concerning the emergency measures adopted by Argentina, such as $C M S, L G \& E$, Sempra and Enron, were swift to side with claimants because they adopted a far-reaching understanding of host States' duty to ensure the stability of the environment in which foreign investments operate.

In $C M S$, the arbitral tribunal held that Argentina's measures resulted in a breach of the FET standard because they "in fact entirely transform and alter the legal and business environment under which the investment was decided and made". ${ }^{53}$ This conclusion rests on a purposive reading of the notion of FET, since the tribunal noted that the Preamble of the applicable BIT recognizes the close link between this standard and the maintenance of "a stable framework for investments and maximum effective use of resources". Therefore, "there can be no doubt" that ensuring the stability of the legal and business framework is "an essential element" of the standard. Subsequent decisions adopted the same line of reasoning, as they considered it "an emerging standard of fair and equitable

\footnotetext{
${ }^{51}$ CMS (n. 37) para. 277.

52 El Paso (n. 38) para. 371.

53 CMS (n. 37) para. 275.
} 
treatment in international law". ${ }^{54}$ The $L G \& E$ decision stands for the same proposition, while further adding that "the fair and equitable standard consists of the host State's consistent and transparent behaviour, free of ambiguity that involves the obligation to grant and maintain a stable and predictable legal framework necessary to fulfil the justified expectations of the foreign investor". 55 Likewise, in Enron, the Tribunal found "an objective breach" of FET, since "the guarantees of the tariff regime that had seduced so many foreign investors were dismantled" and "the stable legal framework that induced the investment is no longer in place". 56

The focus of these decisions was firmly on investors' position and on their expectations, while giving little consideration to the position of the host State and its right to regulate. ${ }^{57}$ Such a bias clearly emerges from the selective reference to the Preamble of the BIT made by the $C M S$ and $L G \& E$ decisions. In both cases, tribunals only retained the first prong of the provision, since it was functional to demonstrating that stability is a constitutive element of FET, while dropping the second one, which would have called for greater consideration of State's capacity to guarantee to its population maximum effective use of its resources. This article argues that such a one-sided approach is ill-suited to defining the content of a standard "entailing reasonableness and proportionality". 58

\section{Reconciling Regulatory Change and Regulatory Stability in the} Context of Public Services: The Way Forward

\subsection{Not Any Expectation is Legitimate: The Need for Specific Commitments}

Subsequent decisions tried to distance themselves from this over-expansive,

\footnotetext{
${ }^{54}$ LG\&E Energy Corp., LG\&E Capital Corp. And LG\&E International Inc. v. The Argentine Republic, ICSID Case No. ARB/02/1, Decision on Liability (3 October 2006) para. 125.

55 Ibid., para. 125. This conclusion echoes the very demanding, and much criticized, standard developed in Tecmed (para. 154). Douglas observed that " $[\mathrm{t}]$ he Tecmed 'standard' is not a standard at all; it is rather a description of perfect public regulation in a perfect world, to which all States should aspire but very few (if any) will ever attain". See Z. Douglas, 'Nothing if not Critical for Investment Treaty Arbitration' (2006) 22 Arbitration International 27, 28.

56 Enron Corporation and Ponderosa Assets, L.P. v. Argentine Republic, ICSID Case No. ARB/01/3, Award (22 May 2007) paras 266-268.

57 This approach seems to reflect what Crema convincingly described as the international investment regime's cultural bias against domestic regulation. Indeed, in this framework "excessive domestic regulation, discriminatory or not, unfair or not, is in any case problematic: it is a local, particularistic obstacle to the bigger game of reallocating resources in a better way for the good of a greater number of persons". See L. Crema, 'Investors' Rights and Well-Being. Remarks on the Interpretation of Investment Treaties in Light of Other Rights', in T. Treves, F. Seatzu and S. Trevisanut (eds), Foreign Investment, International Law and Common Concerns (Routledge 2014) 60-61.

${ }^{58}$ El Paso (n. 38) para. 373.
} 
and excessively pro-investor, reading of the FET standard by tentatively devising a more principled operational test to better define the boundaries of the protection offered by the standard at stake. These arbitral tribunals sought to make it clear that not all expectations of the investor fall within the scope of the FET, but only legitimate ones. Consequently, they sought to identify a number of qualifying requirements to determine whether an expectation may be deemed 'legitimate' and therefore subject to protection under the FET standard. One of the most delicate issues in this regard is the identification of the sources from which legitimate expectations may arise.

The key question is whether private investors can claim to have enforceable expectations simply by relying on legislative or regulatory instruments of a general character, or whether they have to show the existence of more specific promises by the host State. ${ }^{59}$ The answer is decisive in striking a balance between regulatory stability and change because it determines the scope of the host State's duty to maintain 'a stable legal environment'. Indeed, if investors can claim to have legitimate expectations simply by relying on the general legislative and regulatory framework in force when they made the investment, any modification of that framework may entail a violation of FET. This would transform the standard into a sort of general stabilization clause, ${ }^{60}$ fettering States' capacity to regulate their economy and going "beyond what the investor could legitimately expect". ${ }^{61}$

It is worth observing that, by adopting this approach, international arbitral tribunals end up by ensuring private investors a higher level of protection than even national judges ensure. Indeed, the latter have traditionally been extremely cautious in this regard, as "only exceptionally has the concept of legitimate expectations been the basis of redress when legislative action by a State was at stake". ${ }^{62}$ As observed by Steele with regard to the English legal system, "it seems likely that protecting an expectation in a 'change of policy' scenario will have

\footnotetext{
${ }^{59}$ See generally Hirsch (n. 33) 787-797.

${ }^{60}$ See recently P. Bertoli, Z. Crespi Reghizzi, 'Regulatory Measures, Standards of Treatment and the Law Applicable to Investment Disputes', in Treves, Seatzu and Trevisanut (eds) (n. 57) 36.

${ }^{61}$ C. Schreuer, 'Fair and Equitable Treatment in Arbitral Practice' (2005) 11 Journal of World Investment and Trade 357, 374. Contra A. Boute, 'Challenging the Re-Regulation of Liberalized Electricity Prices under Investment Arbitration’ (2011) 32 Energy Law Journal 523, 523-626.

${ }^{62}$ Total S.A. v. The Argentine Republic, ICSID Case No. ARB/04/01, Decision on Liability (27 December 2010) para. 129.
} 
more wide-ranging implications for decisions-maker's freedom of action". ${ }^{63}$ This proposition finds strong support in the case law of the CJEU, which has constantly held that "traders cannot have a legitimate expectation that an existing situation which is capable of being altered by the Community institutions in the exercise of their discretionary power will be maintained". ${ }^{64}$ The reason for a such a restrictive approach is avoiding the risk of regulatory freezing. Indeed, as explained by the CJEU in Brasserie du Pêcheur, "even where the legality of measures is subject to judicial review, exercise of the legislative function must not be hindered by the prospect of actions for damages whenever the general interest of the Community requires legislative measures to be adopted which may adversely affect individual interests". ${ }^{65}$

Conversely, early public service decisions took a different path. In $L G \& E$, for instance, the Tribunal established that Argentina acted unfairly and inequitably by frustrating the claimant's reliance upon "certain key guarantees in the Gas Law and implementing regulation". ${ }^{66}$ Likewise, in Enron, the Arbitral Tribunal found that the dismantling of the tariff regime amounted to a violation of the FET standard, as "it was in reliance upon the conditions established by the Respondent in the regulatory framework for the gas sector that Enron embarked on its investment in TGS. Given the scope of Argentina's privatization process, its international marketing, and the statutory enshrinement of the tariff regime, Enron had reasonable grounds to rely on such conditions". ${ }^{67}$ Despite some passing reference to the need for "specific commitments", these dicta convey the idea that guarantees that can be inferred from domestic legislative and regulatory acts of general application may be sufficient to create legitimate expectations. According to this line of cases, the decisive element in assessing the legitimacy of the expectations is not the origin or the nature of the guarantees, but the fact that investors relied upon them when deciding to invest.

\footnotetext{
${ }^{63}$ I. Steele, 'Substantive Legitimate Expectations: Striking the Right Balance' (2005) 121 Law Quarterly Review 300, 303.

${ }^{64}$ Case 245/81, Edeka Zentrale AG v Germany [1982], ECR 2745, para. 27; Case 52/81, Offene Handelsgesellschaft in Firma Werner Faust v Commission, [1982], ECR 3745, para. 27; Joined Cases 424-425/85, Cooeperative Melkproducentenbedrijven Noord-Nederland BA (Frico) and Others v Voedselvoorzienings In - en Verkoopbureau [1987], ECR 2755, para. 33. See generally P. Craig, EU Administrative Law (Oxford University Press 2006) 635-639; T. Tridimas, General Principles of EU Law (Oxford University Press 2006) 273-280.

${ }^{65}$ Case C-46/93, Brasserie du Pêcheur [1996], ECR 1029, para. 45.

${ }^{66}$ LG\&EE (n. 54) para. 133.

${ }^{67}$ Enron (n. 56) para. 265.
} 
Subsequent arbitral decisions tried to devise a less investor-centred approach to the issue. In Continental Casualty, a case concerning Argentina's insurance market, the Tribunal sought to shed more light on the link between the source of the expectations and their legitimacy. For this purpose, it distinguished between different types of expectations by pointing out that general legislative statements engender only reduced expectations, while "unilateral modification of contractual undertakings by government [...] deserve clearly more scrutiny". ${ }^{68}$ The key element in establishing the legitimacy or, rectius, the legal strength of the expectation is the specificity of the undertaking relied upon by the investor. The El Paso decision tried to further clarify the point by arguing that a commitment is to be considered 'specific' when it is directly made to the investor, "for example in a contract or in a letter of intent, or even through a specific promise in a personto-person business meeting" and "its precise object was to give a real guarantee of stability to the investor" ${ }^{69}$

This approach has gradually made its way also into arbitral decisions concerning public services. The Total decision represents a good case in point. It concerned an investor that had no contractual relationship with the host country, because it had invested after the original privatization process by acquiring an indirect share in the Argentinian gas transportation company (Transportadora de Gas del Norte) from another investor in 2001. To determine whether Argentina's modification of the tariff regime violated Total's legitimate expectations, the arbitral tribunal started by making it clear that signing a BIT cannot be taken as indicating States' will to "relinquish their regulatory powers [or] limit their responsibility to amend their legislation". Therefore, "in the absence of some 'promise' by the host State or a specific provision in the treaty itself, the legal regime in force in the host country at the time of making the investment is not automatically subject to a "guarantee of stability". According to the Tribunal, expectations are "undoubtedly legitimate" when based upon contracts, concessions or stabilization clauses "on which the investor is [...] entitled to rely as a matter of law". ${ }^{70}$ The same holds true for other, albeit less formal, types of representations provided that they are sufficiently clear and specific. ${ }^{71}$

\footnotetext{
${ }^{68}$ Continental Casualty Company (n.46) para. 261.

${ }^{69}$ El Paso (n. 38) paras. 376-377.

70 Total (n. 62) para. 117.

${ }^{71}$ Ibid., para. 121.
} 
However, the Tribunal also acknowledged that problems may arise with regard to certain specific sectors, such as "operation of utilities under a licence", where expectations "rooted in regulation of a normative and administrative nature, that is not specifically addressed to the relevant investor", may be legitimate, due to the "inherently prospective nature of the regulation at issue aimed at providing a defined framework for future operations". ${ }^{72}$ In fact, unilateral modifications to the guarantees contained therein cannot be considered irrelevant when assessing whether the host State acted equitably and fairly. There is only, as duly warned by the Total Tribunal, the need for greater caution because these expectations are inherently weaker than those originating from more specific undertakings. This element is thus to be taken into account when weighing investors' expectations and the host State's regulatory interest in order to determine whether the modification of the regulatory framework constitutes a breach of the FET standard.

\subsection{The Need to Search for State Purpose}

Early public service cases excluded that the purpose pursued by host States when making use of their regulatory powers had any relevance when assessing whether the frustration of investors' expectations amounted to a violation of the FET.$^{73}$ By adopting such an agnostic approach, these arbitral tribunals showed a "deplorable lack of sensitivity with regards to regulatory issues". ${ }^{74}$ Indeed, they focused exclusively on the effects of regulatory changes on investors' positions, while disregarding the reasons why these measures had been adopted. For instance, both the Enron and Sempra decisions curtly observed that "[e]ven assuming that the Respondent was guided by the best of intentions, which the Tribunal has no reason to doubt, there has here been an objective breach of the fair and equitable treatment due under the Treaty". ${ }^{75}$

Even a cursory comparative analysis demonstrates that this approach is at odds with the line of reasoning traditionally followed in domestic and other

\footnotetext{
${ }^{72}$ Ibid., para. 122.

${ }^{73}$ For an insightful analysis on the need to inquire into State purpose with regard in particular to the national treatment standard, see J. Kurtz, 'Balancing Investor Protection and Regulatory Freedom in International Investment Law: The Necessary, Complex and Vital Search for State Purpose' (2013-14) Yearbook of International Investment Law and Policy 280, 280-303

${ }^{74}$ M. Krajewski, 'The Impact of International Investment Agreements on Energy Regulation' (2012) 3 European Yearbook of International Economic Law 343, 366.

75 Sempra (n. 26) para. 304; Enron (n. 56) para. 268.
} 
supranational jurisdictions. Pitting individual expectations against the public interest pursued through the measures challenged is a constant feature of the CJEU case law on this matter. This is well exemplified by Dieckmann \& Hansen, a judgment of the then Court of First Instance concerning an importation ban on fishery products from Kazakhstan, in view of the systemic deficiencies in the general regime of health supervision. A German company, which had concluded a contract to import caviar from that country, brought an annulment action against this decision, arguing that the act violated its legitimate expectations by not including transitional provisions in the decision to remove a country from the list of third countries from which the import of fishery products is authorised. The Court dismissed this claim, as it held that the choice was then taken to protect consumers' health, which is an overriding public interest within the meaning of the case law. ${ }^{76}$

The need to pay due consideration to purpose pursued by the host State through the modification of the regulatory framework is integral to the choice to protect foreign investors' expectations as part of the FET. Indeed, as seen above, this protection is not absolute, but it has to be reconciled with the safeguard of States' ability to regulate. Therefore, modifications of the regulatory framework that pursue a public interest are, in principle, neither unfair nor inequitable. In this regard, more recent arbitral awards, progressively abandoning the agnostic approach seen above and paying due consideration to the State's regulatory purpose, are a step in the right direction. Interestingly, the Total Award motivated the adoption of this approach by referring to the fact that "TGN's gas transportation is not an ordinary business operation but it is qualified as a 'national public service"'. ${ }^{77}$ Consequently, the assessment of whether the modification of the regulatory framework constitutes a breach of investor's legitimate expectations. Hence, a violation of the FET standard must take into account "the purposes, nature and objectives of the measures challenged, so to determine that they are reasonable and proportionate". ${ }^{78}$ In the same vein, the $A W G / S u e z$ Tribunal, ruling on a case concerning "one of the world's largest water distribution and waste water treatment privatizations in a great city" such as Buenos Aires, held that in interpreting the FET standard it "must balance the

\footnotetext{
${ }^{76}$ Case T-155/99, Dieckmann \& Hansen [2001], ECR II-3143, para. 81. See Craig (n. 56) 639-341.

77 Total (n. 54) para. 160.

78 Ibid., para. 162.
} 
legitimate and reasonable expectations of the Claimants with Argentina's right to regulate the provision of a vital public service", ${ }^{79}$

\subsection{Proportionality Analysis and Deference}

Sensitiveness toward host State's intentions has gone hand in hand with the, often tentative, adoption by arbitral tribunals of what can be loosely termed a proportionality analysis. The idea that these elements represent two faces of the same coin emerges clearly in El Paso, where the Tribunal, after having highlighted that legitimate expectations "have to be deduced [...] with due regard to the rights of the State", i.e. "[i]n other words, a balance should be established between the legitimate expectations of the foreign investor to make a fair return on its investment and the right of the host State to regulate its economy in the public interest". 80

Until few years ago, proportionality analysis enjoyed far more success in the literature than in the arbitral practice. ${ }^{81}$ More recently, a growing number of tribunals is turning to this method of review to reconcile investors' expectations and States' right to adapt the regulatory framework. However, many of these references betrays a less-than-systematic approach to this method, as several arbitral decisions tended to jump to the preferred conclusion without elaborating much on the successive argumentative steps. ${ }^{82}$ Yet, recourse to this method of review is welcome, especially with regard to the reconciliation between stability and change under the FET, for a number of reasons. First, it operationalizes the idea according to which that the legitimate expectations doctrine and, thus, the protection of regulatory stability is not absolute, but it "must give way where [its] application becomes incompatible with the free and proper exercise of an

\footnotetext{
79 AWG/Suez (n. 34) para. 236. See A. Tanzi, 'Recent Trends in International Investment Arbitration and the Protection of Human Rights in the Public Services Sector', in N. Boschiero, T. Scovazzi, C. Pitea and C. Ragni (eds), International Courts and the Development of International Law. Essays in Honour of Tullio Treves (TMC Asser Press 2013) 592-596. See also A. Tanzi, 'Public Interest Concerns in International Investment Arbitration in the Water Services Sector. Problems and Prospects for an Integrated Approach', in Treves, Seatzu and Trevisanut (eds) (n. 49) 308-324.

${ }^{80}$ El Paso (n. 38) para. 358 (italics added).

${ }^{81} \mathrm{On}$ the use of proportionality analysis in investment arbitration there is burgeoning literature; see, ex multis, E.M. Lehonardsen, 'Looking for Legitimacy: Exploring Proportionality Analysis in Investment Treaty Arbitration' (2012) 3 Journal of International Dispute Settlement 95, 95-136; B. Kingsbury, S. Schill, 'Public Law Concepts to Balance Investors' Rights with the State Regulatory Actions in the Public Interest - The Concept of Proportionality', in Schill (n. 41), 75-104;

${ }^{82}$ Henckels (n. 47), 107-110 (pointedly criticizing the Termed Award for going directly to the third step of the proportionality test - balancing - without even taking into consideration the other two).
} 
authority's powers on the due performance of its duties in the public interest". ${ }^{83}$ Secondly, this method of review allows for a comprehensive evaluation of all the interests at stake, such as, in this case, protection of foreign investors' expectations and respect for host States' ability to regulate. ${ }^{84}$ Thirdly, it potentially offers a clear analytical structure to make arbitrators' value judgments more explicit and transparent.

For all its merits, arbitral tribunals' reliance upon the proportionality analysis has been severely criticized. Some commentators stressed that this method of review give adjudicators too much discretion and an excessive capacity to intrude into national decision-makers' realm. This is highly problematic when adjudicators, such as international arbitral panels, are not embedded in any polity and not subjects to the institutional limitations that normally apply to courts. ${ }^{85}$ The critique deserve utmost attention, touching upon a key feature of the system. However, one cannot assume that it inevitably leads to abandoning the proportionality analysis, since this concern can be addressed by adjusting the structure of the test and by adopting a deferential standard of review. ${ }^{86}$

First, it is worth recalling that the proportionality analysis is conventionally described as consisting of three steps: suitability, necessity and balancing (or proportionality strictu sensu). Most of the problems lie with the third step, which allows adjudicators to determine whether the burden imposed on foreign investors' expectations is justified in the light of the importance of the interest pursued by the host State. This entails a value judgment as to the relative weight attached by national authorities to the specific interest that motivated their regulatory intervention. Due to their nature and institutional features, arbitral tribunals are particularly ill suited to carry out this type of scrutiny and, consequently, they should focus exclusively on the first two steps. It has been argued that abstaining from this type of control "would allow the severe restriction of a right in order to protect a negligible public interest". ${ }^{87}$ This remark is problematic more for its premises than for its content. Indeed, it presupposes

\footnotetext{
${ }^{83}$ W. Wade, C. Forsyth, Administrative Law (Oxford University Press 2000) 242.

${ }^{84}$ Contra W.W. Burke-White, A. von Staden, 'Private Litigation in a Public Sphere: The Standard of Review in Investor-State Arbitration' (2010) 35 The Yale Journal of International Law 283, 287.

${ }^{85} \mathrm{~J}$. Kurtz, 'Adjudging the Exceptional at International Investment Law: Security, Public Order and Financial Crisis' (2010) 59 International and Comparative Law Quarterly 325, 367-368.

${ }^{86}$ F. Ortino, 'Investment Treaties, Sustainable Development and Reasonableness Review: A Case Against Strict Proportionality Balancing' (2017) 30 Leiden Journal of International Law 71, 71-91.

${ }^{87}$ Kingsbury/Schill (n. 81) 87.
} 
that arbitral tribunals are entitled to decide whether a public interest is negligible or not. Conversely, the present article contends that only national authorities are in the position to attach a weight to a public interest, while arbitral tribunals cannot substitute for their judgment. ${ }^{88}$

Second, arbitral tribunals should adopt a deferential standard of review ${ }^{89}$ when evaluating suitability and necessity of host States' measures. The reasons that justify the adoption of a deferential approach in international arbitral adjudication have already been thoroughly and convincingly analysed elsewhere ${ }^{90}$ and, therefore, there is no need to reconsider them. What is worth highlighting here is that the main rationales for deference identified by those scholars - such as normative and empirical uncertainty, regulatory autonomy and proximity, as well as institutional competence and expertise - are very much relevant in the case of public services. As seen above, regulating public services is one of States' core sovereign functions, essential for the wellbeing of their population and for the enjoyment of fundamental human rights. Furthermore, the exercise of this function is intrinsically linked to democratic autonomy and it involves delicate questions of resource allocation that are inherently discretional and that call for an intimate knowledge of the socio-political context. For all these reasons, international adjudicators are not in the position to adopt too an intrusive approach because they must fully respect national decision-makers' broad discretionary space in this field.

The most troubling aspect in this respect concerns the necessity analysis. It is worth observing that, when performing this analysis, the ECHR has consistently adopted a deferential approach, on the basis that "national authorities are in principle better placed than the international judge to appreciate what is in "the public interest". Therefore, as made clear in James and Others $v$. UK, "the possible existence of alternative solutions does not in itself render the contested

\footnotetext{
${ }^{88}$ See also P. Ranjan, 'Using the Public Law Concept of Proportionality to Balance Investment Protection with Regulation in International Investment Law: A Critical Appraisal' (2014) 3 Cambridge Journal of International and Comparative Law 853, 881-882.

${ }^{89}$ Many scholars highlighted the considerable amount of uncertainty that sorrounds the determination of the standard of review in international arbitration. See C. Henckels, 'Indirect Expropriation and the Right to Regulate: Revisiting Proportionality Analysis and the Standard of Review in Investor-State Arbitration' (2012) 15 Journal of International Economic Law 223, 234-238; S. Schill, 'Cross-Regime Harmonization Through Proportionality Analysis; The Case of International Investment Law, the Law of State Immunity and Human Rights' (2012) 27 ICSID Review - Foreign Investment law Journal 87, 87-119.

${ }^{90}$ Henckels (n. 47) 32-40.
} 
legislation unjustified. Provided that the legislature remains within the bounds of its margin of appreciation, it is not for the Court to say whether the legislation represented the best solution for dealing with the problem or whether the legislature's discretion should have been exercised in another way". ${ }^{91}$

Conversely, the analysis of the arbitral practice concerning public services reveals the existence of cases where arbitral tribunals have adopted a far more intrusive approach. In $A W G / S u e z$, for instance, the Tribunal found that the contested measures failed to pass the necessity test, by finding that Argentina could have "employed more flexible means" to achieve the same ends. In so doing, it identified some alternative measures that Argentina could have taken instead of altering the legal framework and the concession. In particular, the Tribunal opined that, to protect the most impoverished part of the population from increased tariffs and, thus, make sure that it could have access to water services, national authorities "might have allowed tariff increases for other consumers while applying a social tariff or a subsidy to the poor". ${ }^{92}$ The most troubling aspect of this part of the decision is the carelessness with which the arbitral tribunal applied a test that intrudes deeply into matters lying at the heart of States' regulatory space. Indeed, when called upon to review the necessity of the measure, it simply identified a potential alternative to which Argentina could have resorted, without paying any attention to its feasibility in light of the constraints imposed on the government's capacity to intervene by a financial crisis of the magnitude of the one gripping Argentina at that time. The interpretative approach followed by the tribunal makes the necessity test a virtually insurmountable obstacle for the State seeking to justify the adopted measure because, if one ignores reality, there will always be a hypothetical less restrictive alternative that the host State should have adopted. Furthermore, the tribunal failed to consider that, in fact, Argentina had actually tried to cope with the crisis by adopting measures other than those challenged by the Claimant. Between 2000 and 2001, Argentina sought to buttress the peso's convertibility by obtaining emergency financial assistance from the IMF, and despite growing resentment in the population, it did not alter the legislative and regulatory framework of the utility

\footnotetext{
${ }^{91}$ James and Others $v$. the United Kingdom, judgment of 21 February 1986, Series A no. 98, para. 51. See also Zolotas v. Greece (no. 2), judgment of 29 January 2013, no. 66610/09, para. 44; J.A. Pye (Oxford) Ltd. $V$. United Kingdom, judgment of 15 November 2005, no. 44302/02, paras. 43-42. W.A. Schabas, The European Convention on Human Rights (Oxford University Press 2015) 975-976.

$92 A W G /$ Suez (n. 34) para. 235.
} 
sectors. It was only in 2002, with the adoption of the Emergency Law, that Argentine authorities decided to modify public services' regulatory framework.

Other arbitral decisions concerning the same factual scenario have adopted a more cautious approach. In $L G \& E$, the Tribunal rejected the claim that Argentina's emergency measures were not necessary and, hence, disproportionate for not being "the only means available to respond to the crisis". Indeed, although admitting that the Government had other available options, the Tribunal held that "suspension of the calculation of tariffs in U.S. dollars and the PPI adjustment of tariffs was a legitimate way of protecting its social and economic system". ${ }^{93}$ Likewise, Arbitrator Nikken called for the adoption of a similarly deferential approach in his dissenting opinion in $A W G / S u e z$. In particular, he argued that, when assessing the necessity of the measures, tribunals should just assess "whether the various measures taken by Argentina were such that any reasonably good government of a well-organized modern State could have adopted" and not "substitute itself for the Argentine Government when it had to address the serious crisis that hit the country". ${ }^{94}$

\section{Conclusion}

In the public services' sector, regulation is the main tool for public authorities to pursue fundamental social objectives by ensuring access to high-quality services. Indeed, over the past decades many States have privatized or liberalized the provision of public services by progressively transferring to private actors some of the functions traditionally performed by public entities. However, the choice of moving along this path does not deprive States of their right to regulate the organization and the supply of public services; nor does it absolve them from their duty to guarantee the continuous realization of the rights that depend on the provision of these services.

In exercising these functions, States resort to a variety of regulatory tools, which are often contained in different legal instruments, such as constitutional norms, legislative acts, administrative regulations and contractual agreements stipulated with the private provider. Foreign operators investing in this sector may challenge before an international arbitral tribunal any modification of the

\footnotetext{
${ }^{93}$ LG\&E (n. 54) para. 239.

${ }^{94}$ Dissenting Opinion Nikken (n. 44) para. 37.
} 
regulatory framework if it violates rules or standards contained in an international investment agreement.

The impact of international investment law on States' capacity to modify the regulatory framework governing public services depends on the definition treaties' provisions and, in particular, on the willingness of arbitral tribunals to pay due regard to the specific social value of these activities. Early arbitral decisions tended to consider regulatory stability as an absolute priority by showing a deplorable lack of sensitivity to any competing objective.

This was the case with regard to the FET standard, as arbitral tribunals sought to progressively expand its scope in order to strengthen the position of foreign investors. In particular, they took the view that one of the FET's main components is host State's duty to ensure the stability of the investment's regulatory framework, by avoiding any modification that may frustrate investors' legitimate expectations. If taken too rigidly, this duty may fetter host States' capacity to adapt the legislative environment to ever-changing needs and challenges. Despite acknowledging the need to guarantee an adequate regulatory space to national authorities, especially in a sector such as public services, some early decisions adopted an over-broad reading of the duty to protect investors' expectations, paying little attention to States' regulatory purposes.

More recent decisions have shown a slightly greater sensitivity to these concerns, trying to accommodate host States' right to regulate and investors' expectations. In some cases, arbitral tribunals have motivated the shift toward a more balanced approach by referring to the fact that the activity was not an ordinary commercial one, but a public service. This article sought to systematize these efforts, proposing an interpretive approach that combines three different aspects so to contribute to the reconciliation of stability and change in this context.

First, arbitral tribunals have to recognize that not any expectation that the investor had when it decided to invest can be protected, because only 'legitimate' ones fall within FET's scope of application. Some arbitral awards have already moved along this path, making it clear that expectations can be taken into consideration only if grounded on a specific commitment given by the host State to the investor.

Second, arbitral tribunals need to search for host State's regulatory purpose 
when assessing whether a modification of the regulatory framework does represent a violation of investors' legitimate expectations. More recent arbitral awards have progressively abandoned the lack of sensitivity shown by earlier decision toward this aspect. This is a welcome evolution that builds on the idea that the protection of investors' expectations is not absolute, as it can be accorded only in so far it does not unduly encroach upon host States' capacity to respond to pressing social needs.

Third, increased sensitiveness toward this issue should come together with the adoption by arbitral tribunals of a proportionality analysis. This method allows for the reconciliation of all the interests at stake, operationalizing the idea that the protection of regulatory stability need to be reconciled with other competing objectives. Due to their institutional features and their remoteness form the relevant polity, international arbitral tribunals should limit their scrutiny to the first two steps of the proportionality test and adopt a deferential standard of review. This exercise of judicial restraint does not deprive international arbitrators of their capacity to assess whether the modification of the regulatory framework was unjust or unfair, while, at same time, avoiding to unduly encroaching upon host States' ability to meet new needs and challenges. This is all the more urgent when the regulation of public services is at stake, being it a core sovereign function that is essential for the well-being of the population and that touches upon key aspects of States' democratic autonomy and legitimacy. In this context, regulatory stability cannot not be ensured at any cost. 